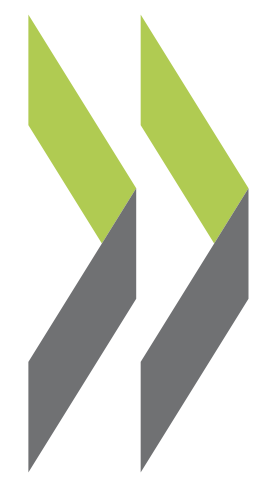

OECD Economics Department Working Papers No. 183

Structural Unemployment

in Denmark

Agnete Gersing

https://dx.doi.org/10.1787/385233524308 


\section{ECONOMICS DEPARTMENT}

WORKING PAPERS

No. 183

STRUCTURAL UNEMPLOYMENT IN DENMARK

by

Agnete Gersing

Most Economics Department Working Papers beginning with No. 144 are now available through OECD's Internet Web site at http://www.oecd.org/eco/eco.

\section{ORGANISATION FOR ECONOMIC CO-OPERATION AND DEVELOPMENT}

\section{Paris}

56453

Document complet disponible sur OLIS dans son format d'origine

Complete document available on OLIS in its original format 


\section{BSTRACT/RÉSUMÉ}

The paper gives a broad discussion of structural unemployment seen from a Danish perspective. In the Danish Ministry of Finance the level of structural unemployment is estimated using two indicators - NAIRU and ITRU. The two indicators basically reflect variations in unemployment and inflation as measured by the GDP-deflator and are computed using historical simulations with the national macro-econometric model ADAM.

The uncertainty related to estimates of the level of structural unemployment calls for a great deal of caution when using such estimates in the framing of economic policy. Estimates of structural unemployment can nevertheless be useful when making forecasts of inflation and assessing the appropriate fiscal stance and - not least - when assessing the effectiveness of labour market policies and the possible need for changes. For the purpose of policy-making it is useful to make clear to what extent structural unemployment can be ascribed to "employability" problems of individuals or rather problems of "market-ineffectiveness". It is argued, that the problems of structural unemployment in Denmark can primarily be ascribed to a poorly functioning market and, consequently, that unemployment could be lowered substantially by a broad range of policy-measures such as training and education, administrative tightenings and targeted measures vis$\grave{a}$-vis long term unemployed in line with the reforms of the Danish labour market system implemented since 1993.

Though having a high unemployment rate compared to most countries, significant challenges still relate to a high number of transfer receivers outside the labour force. The policy-measures implemented is thus expected to improve the functioning of the labour market substantially, inducing a drop in structural unemployment from 10 per cent in 1993 to a level of approximately 7 per cent by the year 2000. At the time of writing end of 1996-figures show an unemployment rate of 8.2 per cent, broadly in line with unchanged and low inflation. Harmonised EU-figures are down to 6.1 per cent.

$$
* * * * *
$$

Cet article présente une discussion générale de la question du chômage structurel selon une perspective danoise. Au Ministère des finances du Danemark, le niveau de chômage structurel est mesuré à partir de deux indicateurs : le NAIRU et l'ITRU. Ces deux indicateurs, qui reflètent les liens existant entre le chômage et l'inflation - mesurée par le déflateur du PIB - sont estimés à partir de simulations effectuées sur période historique avec le modèle macro-économique national ADAM.

Les incertitudes inhérentes aux estimations du niveau du chômage structurel imposent une très grande prudence lors de l'utilisation de telles estimations pour la définition de la politique économique. Ces estimations du chômage structurel peuvent néanmoins être utiles pour effectuer des prévisions d'inflation, évaluer l'orientation appropriée de la politique budgétaire et, surtout, pour analyser le degré d'efficacité des politiques du marché du travail afin, si nécessaire, de les modifier. Il est utile, pour la mise en oeuvre des politiques économiques, de clarifier dans quelle mesure le chômage structurel traduit des problèmes "d'employabilité" des individus ou plutôt des problèmes de dysfonctionnement des marchés. Dans le cas du Danemark, il apparaît que les problèmes structurels de chômage résultent principalement d'un mauvais fonctionnement du marché. En conséquence, le chômage peut être réduit significativement par un large éventail de mesures de politique économique portant sur la formation et l'éducation et sur le resserrement des procédures administratives ainsi que des actions ciblées sur les chômeurs de longue durée comme celles mises en oeuvre depuis 1993 avec les réformes du marché du travail au Danemark.

Alors que le niveau du chômage reste élevé par rapport à la plupart des autre pays, le grand nombre des personnes ne faisant pas partie de la population active et percevant des rémunérations sous forme de transferts pose d'importants problèmes. Les mesures de politique économique mises en oeuvre devraient donc significativement améliorer le fonctionnement du marché du travail et induire une baisse du chômage structurel de 10 pour cent en 1993 à environ 7 pour cent en l'an 2000. Au moment de la rédaction de cet article, fin 1996, les chiffres indiquent un taux de chômage de 8.2 pour cent, alors que l'inflation est stable et faible. Sur la base des chiffres harmonisés de l'Union européenne, le chômage a été réduit à 6.1 pour cent.

\section{Copyright OECD 1997}

Application for permission to reproduce or translate all, or part of this material, should be made to: Head of Publications Service, OECD, 2 rue André-Pascal, 75775 Paris Cedex 16, France. 


\section{TABLE OF CONTENTS}

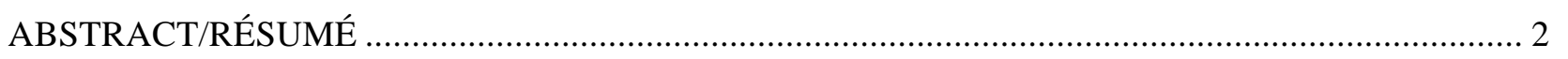

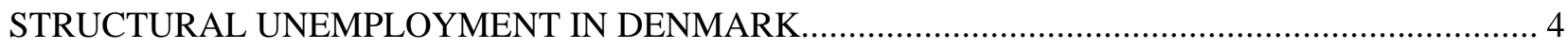

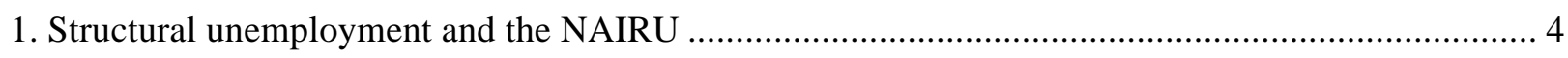

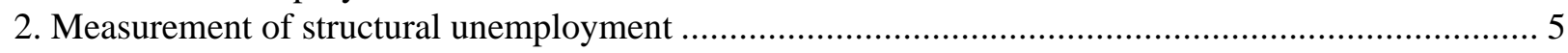

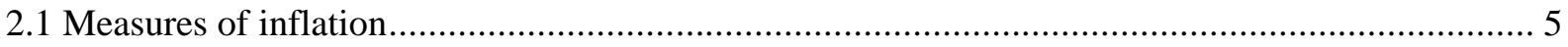

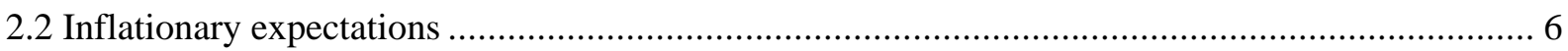

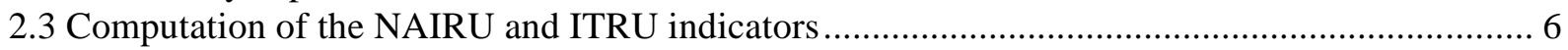

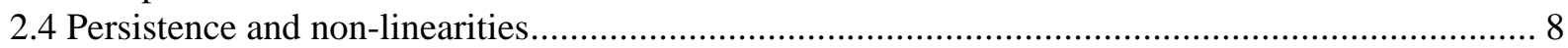

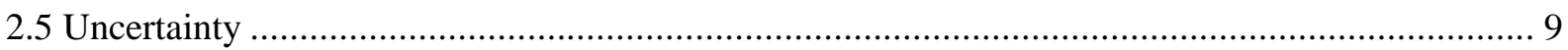

2.6 Indicators of structural unemployment and the framing of economic policy ............................... 9

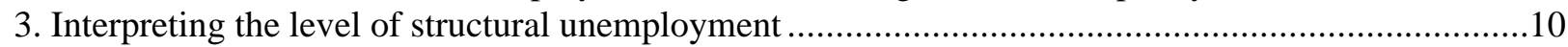

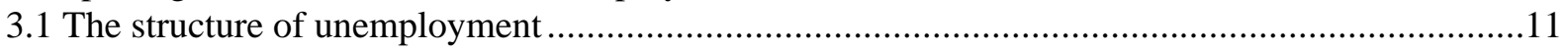

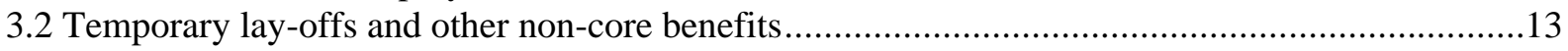

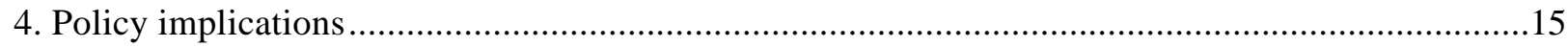

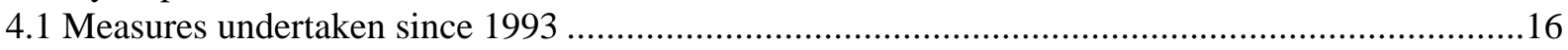

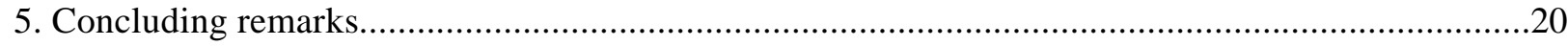

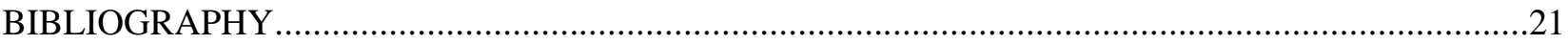




\title{
STRUCTURAL UNEMPLOYMENT IN DENMARK
}

\author{
Agnete Gersing ${ }^{1}$
}

The paper is organised as follows: Section 1 gives a discussion of the concept of structural unemployment and the NAIRU. Section 2 depicts the approach of the Ministry of Finance with regard to measuring structural unemployment - including a discussion of the degree of uncertainty - and outlines the way the indicators are used in the framing of economic policy. Section 3 contains a discussion of how to interpret the level of structural unemployment, i.e. what kind of problems do such indicators reflect, and Section 4 contains a discussion of the policy implications following from this. Finally, concluding remarks are given in Section 5.

\section{Structural unemployment and the NAIRU}

1. The concept of structural unemployment is related to the fact, that the rate of inflation can be high - and increasing - even though the rate of unemployment is relatively high. Structural unemployment might be defined as the level of unemployment compatible with stable inflation in a medium-term perspective. This definition implies that macroeconomic policy cannot permanently reduce unemployment below the structural level. This somewhat pragmatic definition of structural unemployment is not synonymous with the theoretical term NAIRU, although closely related.

2. NAIRU is the level of unemployment compatible with non-accelerating (or rather, nonincreasing) inflation. In case of unemployment persistence, i.e. if wage- and price setting behaviour depend not only on the level of unemployment but also on the change in unemployment, one can define a short-run NAIRU as well as a long-run NAIRU (Layard et al. 1991). The latter depends exclusively on the "true" structural and institutional factors influencing wage- and price behaviour in the economy whereas the first also depends on the actual level of unemployment.

3. The pragmatic definition of structural unemployment given above corresponds neither to a "pure" short- run or long-run NAIRU, but rather something in between depending on the changes in actual unemployment. However, in case actual unemployment does not change the two theoretical concepts will coincide and be more or less synonymous with the pragmatic definition of structural unemployment. If actual unemployment equals the structural rate and if unemployment has been constant for some time, inflation will be (approximately) constant, whereas a reduction in unemployment below the structural level will give rise to steadily increasing - or at least unsustainably high - inflation.

1. Danish Ministry of Finance. 


\section{Measurement of structural unemployment}

4. The level of structural unemployment can be estimated on the basis of the observed variation in unemployment and inflation, using either a reduced form equation or a comprehensive macroeconometric model.

5. In the Ministry of Finance indicators of structural unemployment are calculated using a comprehensive macroeconometric model (see Section 1). However, irrespective of whether one uses a reduced form equation or a more comprehensive model, this kind of estimation poses at least two major problems: one is which measure of inflation to use - wage inflation versus price inflation, consumer prices versus producer prices, and how to take account of the impact from import prices and exchange rate fluctuations in open economies; another problem is how to deal with inflationary expectations.

\subsection{Measures of inflation}

6. Inflation depends not only on domestic factors but also on the changes in import prices - at least in the short run. In consequence of the interaction between wage- and price formation, this holds true for wage inflation as well as price inflation - although the impact on prices is more direct than the impact on wages. By way of affecting import prices, exchange rate changes might reinforce inflationary pressures depending on the exchange rate regime.

7. The level of activity might affect inflation primarily through the wage formation process, but the level of activity can also directly affect the price setting behaviour of producers. Thus presumably, using a measure of price inflation better captures all the relevant factors affecting structural or equilibrium unemployment. Another argument for using measures of price inflation rather than measures of wage inflation is that an acceleration in the rate of wage increases need not be inflationary in nature as it can also reflect extraordinary gains in productivity.

8. Furthermore, the fact that inflationary targets relate to price inflation is in itself an argument for using measures of price inflation when estimating structural unemployment. Using measures of price inflation thus ensures that the central sustainability indicator of economic development - inflation - is in accordance with the estimated slack in the economy.

9. The main problem relating to measures of price inflation is obviously that inflationary pressures originating abroad are reflected in the indicators of structural unemployment - although such pressures have no direct relation to domestic slack. The impact from circumstances abroad can, however, be reduced by using a measure of price inflation less sensitive to changes in import prices, e.g. the GAPdeflator. Furthermore, it can be argued that any kind of inflationary pressure will impose restrictions in relation to economic policy and accordingly unemployment.

10. Another problem is that focusing on price inflation may imply a bias if producers tend to smooth prices over the business cycle, which to some extent seems to be the case in Denmark (Ministry of Finance 1995a). In that case indicators based on measures of price inflation will tend to underestimate the "true" level of structural unemployment in the preliminary phases of recoveries and vice versa when the economy enters a downturn.

11. The estimated indicators of structural unemployment used in the Ministry of Finance is based on the observed variation in the GDP-deflator and unemployment. Using the GDP-deflator implies that the impact from import prices are indirect. 
12. In order to take explicitly into account the uncertainty relating to expectations formation, the Ministry of Finance computes two indicators of structural unemployment - NAIRU (Non-Accelerating Inflation Rate of Unemployment) and ITRU (Inflation Target Rate of Unemployment).

13. The NAIRU-indicator is the level of unemployment compatible with constant inflation. The NAIRU-indicator is relevant if expected inflation moves along with actual inflation, for example if expected inflation corresponds to actual inflation in the previous year. Thus the value of the NAIRUindicator basically depends on how the change in inflation varies with unemployment.

14. The other indicator, ITRU, is the level of unemployment compatible with inflation equalising the inflation target $(2 \text { per cent })^{2}$. ITRU is relevant provided that agents perceive the given inflation target as being credible. Thus presumably, the existence of a credible inflation target acts as an "anchor" of inflationary expectations, reducing the rise in expected inflation in the face of shocks that make actual inflation go up. The value of the ITRU-indicator basically depends on how the level of inflation varies with unemployment.

15. As the level of inflation has undergone considerable changes in Denmark up until the end of the 1980s, and since there has been no inflation target until recently, the ITRU-indicator cannot be considered an appropriate indicator of structural unemployment any earlier than the end of the 1980s.

\subsection{Computation of the NAIRU and ITRU indicators}

16. The two indicators NAIRU and ITRU are computed using historical simulations with the national macro-econometric model ADAM. In the ADAM-model unemployment affects wage- and price formation with a lag of one year. Thus, the value of the NAIRU and ITRU indicators in a given year reflects the actual level of unemployment in that year and the rate of inflation in the following year.

17. More specifically the procedure is as follows: For consecutive periods of two years private sector demand in the first year is scaled proportionally up or down, until the rate of inflation as measured by the GDP-deflator in the following year equals either the rate of inflation the year before (NAIRU) or the upper limit of the inflation target zone (ITRU). The simulation of each two-year period is carried out as static simulations and is thus based on the actual historical values of unemployment and inflation. The structure of wage and price formation in the model is outlined in Box 1.

2. The Danish inflation target reflects the inflation targets in the "core" EU-countries, including Germany, i.e. approximately 2 per cent (Financeredegфrelse 1996, Ministry of Finance). Monetary policy being devoted to the objective of currency stability, the inflation target is used in the framing of fiscal policy. Beyond this, considering the adverse effects on the pubic finances, fiscal rather than monetary tightenings are to prefer. Inflation being higher than approximately 2 per cent thus indicates a need for fiscal tightening. 


\section{Box 1. Wage-and price formation in model used for deriving indicators of structural unemployment}

In the ADAM - model the wage formation equation has the following form:

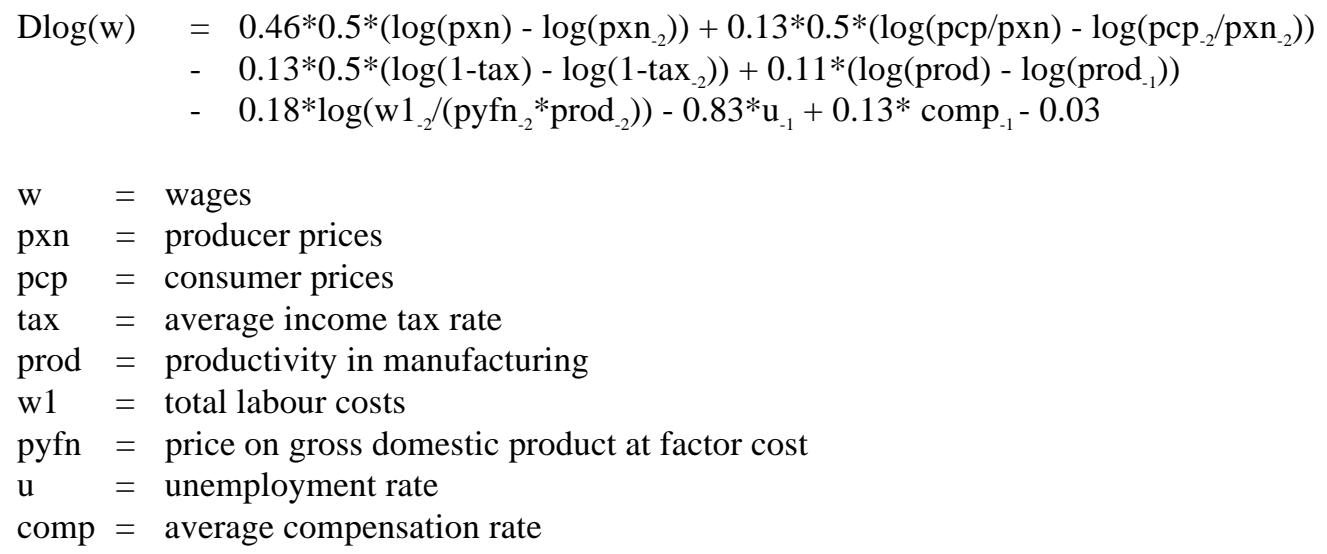

Prices are determined as a mark-up on wages, raw materials and capital costs in an error correction set-up.

Note: The specification of the wage equation implies that the wage formation process is influenced by consumer prices (i.e. the real wage for wage earners) as well as producer prices (i.e. the real wage for employers).

18. The "raw-series" of structural unemployment resulting from this simulation process will obviously be influenced by more or less random or temporary fluctuations in the rate of inflation (especially NAIRU, which reflects the changes in inflation). Furthermore, the indicators might display a bias due to persistence and non-linearities (Figure 1). For these reasons, the "raw-series" are smoothed using a Hodrick-Prescott filter with a smoothing factor of 75 . The final result is shown in Figure 1 together with actual unemployment. 
Figure 1. Indicators of structural unemployment in Denmark

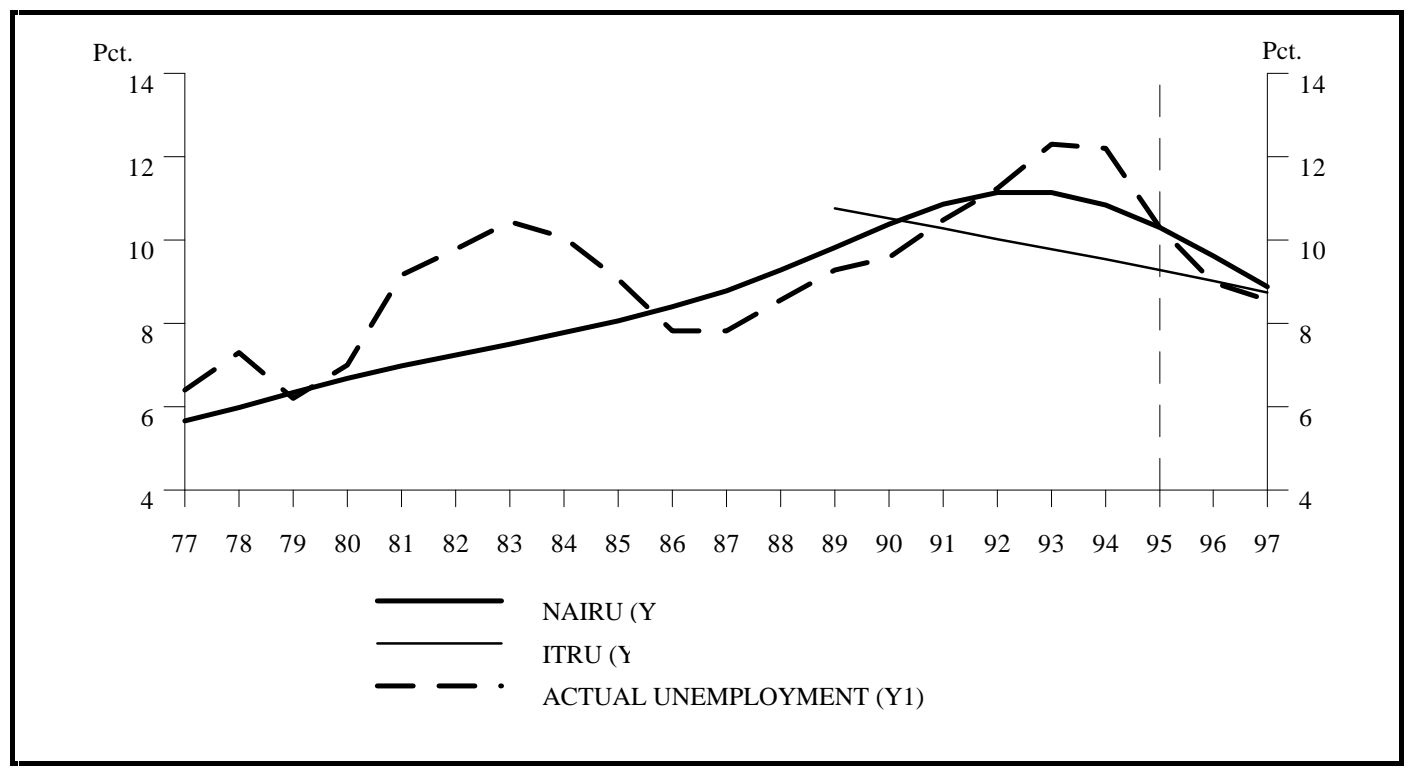

Source: Danish Ministry of Finance and Statistics Denmark.

\subsection{Persistence and non-linearities}

19. In the ADAM model, the rate of wage inflation is determined as a (linear) function of the level of unemployment whereas changes in unemployment are not included in the specification. If nevertheless there is unemployment persistence, i.e. wage and price behaviour depends on the changes in unemployment as well as on it's level, both indicators - most markedly the NAIRU-indicator - will tend to overestimate the level of structural unemployment in periods of decreasing unemployment. Presumably, this tendency will be particularly pronounced in the face of large and rapid changes in unemployment.

20. The NAIRU- and ITRU-indicators can also display a bias, if the impact of unemployment on inflation is asymmetric rather than linear as indicated by recent international evidence (Turner 1995 and Laxton et al. 1995). If relatively high levels of unemployment result in only small reductions in inflation whereas relatively low levels of unemployment result in large increases in inflation, the NAIRU- and ITRU-indicators will tend to overestimate the level of structural unemployment. The degree of bias will depend on the variance in inflation.

21. The potential biases due to persistence and non-linearities stress the need for caution when assessing the level of structural unemployment on the basis of the NAIRU- and ITR-indicators, particularly in times of large changes in the level of unemployment.

22. Given the estimation process, the subsequent smoothing and the potential biases mentioned above, it is obviously not possible to establish with certainty whether the resulting indicators mainly reflect a short-run or a long-run NAIRU. However, if interpreted cautiously, it seems likely that the two indicators seen as a whole give a fairly good indication of the level of structural unemployment as defined in section one. 
23. Taking into account the potential bias in the NAIRU- and ITRU-indicators, structural unemployment can be estimated to approximately 9 per cent of the labour force in 1995 (Figure 1). Given the present level of unemployment and inflation the indicators point to a reduction in structural unemployment in 1996 and 1997, assuming that the forecast of inflation for 1997 and 1998 prove to be correct.

24. This reflects that the rate of unemployment has fallen considerably with rather modest effects on inflation (Table 1). This again might - at least in part - be explained by the labour market reform which came into force in January 1994 and the several subsequent tightenings of labour market policies, (Section 4).

Table 1. Latest trends in unemployment and inflation

\begin{tabular}{|c|c|c|c|c|c|c|c|c|}
\hline & 1993 & 1994 & 1995 & 1996 & 1996Q1 & 1996Q2 & 1996Q3 & 1996Q4 \\
\hline \multirow[t]{2}{*}{ Unemployment $^{1}$} & 12.3 & 12.2 & 10.3 & 8.8 & 9.2 & 8.9 & 8.8 & 8.2 \\
\hline & \multicolumn{8}{|c|}{ Per cent increase } \\
\hline Hourly earning & 2.4 & 4.2 & 3.7 & - & 4.2 & 4.2 & 3.8 & - \\
\hline Consumer prices & 1.2 & 2.0 & 2.1 & 2.1 & 1.9 & 2.0 & 2.3 & 2.4 \\
\hline GDP deflator & 0.7 & 1.7 & 1.7 & - & 1.9 & 2.0 & 2.3 & - \\
\hline
\end{tabular}

1. Per cent of labour force. Quarterly figures are seasonally adjusted.

Note: The rise in wage inflation from 1993 to 1994 might have been affected by extraordinary circumstances such as a jump in productivity and profits and special factors in 1993.

Source: Statistics Denmark and Danish Employers Confederation.

\subsection{Uncertainty}

25. In principle, it would be possible to calculate the statistical uncertainty relating to the "rawseries" of the NAIRU- and ITRU-indicators. However, given the uncertainties relating to the specification of the macro- econometric model used for the estimations, including the potential biases due to persistence and non-linearities, the possibility of producers smoothing prices over the business cycle and - not least the smoothing procedure using a Hodrick-Prescott filter, such calculations would not be of much use.

26. As to the historical estimates the uncertainty is probably rather limited. Hence, during the past ten to 15 years unemployment has varied roughly between 8 and 12 per cent of the labour force with predictable effects on inflation. Consequently, there seems to be little doubt that the level of structural unemployment in this period has been somewhere in between 8 and 12 per cent.

27. However, as the estimates of the present level of structural unemployment are based on a forecast of inflation, it is also quite clear that the degree of uncertainty relating to estimates of the actual level of structural unemployment is somewhat larger. It is extremely difficult to assess exactly the degree of uncertainty, but presumably uncertainty increases with the actual changes in unemployment.

\subsection{Indicators of structural unemployment and the framing of economic policy}

28. The uncertainty relating to the estimates of the actual level of structural unemployment calls for a great deal of caution when using such estimates in the framing of economic policy. 
29. In the Ministry of Finance estimates of the actual level of structural unemployment influences the framing of economic policy in primarily two ways. Firstly, estimates of structural unemployment are taken into account when making forecasts of inflation and, therefore, when assessing the appropriate fiscal stance. Secondly, estimates of structural unemployment and - not least - the development in these over time are taken into account when assessing the effectiveness of labour market policies and the possible need for changes.

30. It is, however, important to stress that even though estimates of structural unemployment do matter, the framing of economic policy is fundamentally based on the premise that the level of structural unemployment is uncertain and can be highly influenced by economic policy. The conclusion is, that irrespective of the perceived level of structural versus actual unemployment it is necessary to "feel ones way ahead" and in particular monitor actual inflation closely.

\section{Interpreting the level of structural unemployment}

31. Indicators of structural unemployment are deductible from macroeconomic data on unemployment and inflation. However, such indicators are often considered to be abstract and remote from practical decision making in labour market policy. Hence, filling the gap between the macroeconomic indicators on the one side and microeconomic observations and specific policy measures on the other side poses a major challenge.

32. The level of structural unemployment reflects many different aspects, i.e. the wage bargaining system, the unemployment benefit system including eligibility and availability rules, tax rates, the scale and character of active labour market measures, hiring and firing rules, the educational composition of the labour force, the intensity of product market competition, etc.

33. In relation to policy-making it seems useful to distinguish between two different channels by which these structural and institutional factors can be seen as affecting structural unemployment.

34. Firstly, some of the above mentioned factors affect the "employability" of individuals. High minimum wages - which may be induced by high benefit levels - can make it difficult for low-productive individuals to find a job. This way, low-productive individuals can be "priced out of the market". The long term unemployment - or at least part of it - may be seen as an indicator of such employabilityproblems of individuals;

35. Secondly, the different structural and institutional factors may affect the "effectiveness" of the labour market, i.e. the ability of the market to match demand and supply and thus prevent inflationary pressures from emerging. Such "market-ineffectiveness" problems can reflect both search-ineffectiveness, where vacancies and unemployment exist simultaneously but imperfect information or insufficient incentives for the unemployed prevents matching, and mismatch problems, where skills and/or location of the unemployed do not match the requirements of jobs offered;

36. If say 100000 persons are able to carry out a particular type of job but only 80000 jobs of that type are available, it can be ascribed to "market-ineffectiveness" rather than employability problems of individuals. The incidence of shorter spells of unemployment (e.g. up to nine to 12 months) - with the exception of temporary lay-offs (see below) - can be seen as an indicator of such "market-ineffectiveness" problems, although these problems can affect long term unemployment as well. The relative importance of these two "transmission mechanisms" has important implications for the effectiveness of different policy measures aiming at combating structural unemployment. 
37. For example, tightening of availability requirements or shortening of the benefit period may have little effect if structural unemployment is primarily due to employment problems of individuals, but the two instruments will indeed be effective if the major part of the problem can be ascribed to "marketineffectiveness". The fact that reductions of benefit levels and minimum wages might be considered a sufficient, but not necessary condition for lowering structural unemployment in the case of marketineffectiveness is another example. Thus, before drawing conclusions about the effectiveness of different policy measures, it is necessary to look further into the causes of the unemployment problem.

\subsection{The structure of unemployment}

38. Long term unemployment - here defined as the contribution to average unemployment by those being unemployed more than 70 per cent of the year - accounted for approximately half of total unemployment in 1994 (Table 2). However, seen over a period of three consecutive years the incidence of long term unemployment is substantially lower. For the period 1992-1994 the incidence of long term unemployment according to the above definition (the number of persons being unemployed for more than 70 per cent of the three year period) amounted to approximately 30 per cent of total unemployment. The difference between the incidence of long term unemployment measured in one year and over a period of three years respectively reflects a substantial flow out of and in to long term unemployment.

Table 2. Incidence of different spells of unemployment 1994 and the three-year period 1992-94

\begin{tabular}{c|c|c}
\hline Spell of unemployment ${ }^{1}$ & $\begin{array}{c}1994 \\
\text { Contribution to total unemployment in per cent }\end{array}$ \\
\hline $0.0-0.1$ & 2.8 & 1.3 \\
$0.1-0.2$ & 4.4 & 8.8 \\
$0.2-0.3$ & 6.1 & 9.2 \\
$0.3-0.4$ & 7.0 & 11.0 \\
$0.4-0.5$ & 9.1 & 10.6 \\
$0.5-0.6$ & 8.4 & 13.2 \\
$0.6-0.7$ & 9.7 & 14.6 \\
$0.7-0.8$ & 9.4 & 20.7 \\
$0.8-0.9$ & 10.1 & 6.8 \\
$0.9-1.0$ & 33.0 & 3.8 \\
\hline Total & & 100.0 \\
\hline
\end{tabular}

1. Spells of unemployment in percentage of the year or the three-year period. 0.1-0.2 denotes the number of unemployed, who have been unemployed more than 10 and less than 20 per cent of the year (three-year period), i.e. for approximately $1-2 \frac{1}{2}(3-71 / 2)$ months, as a share of the total number of unemployed.

Note: Active labour market policy schemes do imply a downward bias in the contribution from longer spells of unemployment.

Source: Statistics Denmark; Danish National; Institute of Social Research and Ministry of Finance.

39. Another definition of long term unemployment is the number of persons who have been unemployed for one year or more. According to this definition long term unemployment accounted for approximately 30 per cent of total unemployment in 1994, which is a relatively low figure compared to other European countries and to countries with similar rates of total unemployment in general. For EU as 
a whole, the incidence of long-term unemployment was 47 per cent in 1994 (European Commission 1995). Recent evidence illustrates the quite substantial flow into and out of the group of long term unemployed.

40. Defining the "marginal group" as the number of persons who have been unemployed for at least 70 per cent of the time over a period of three years, a Danish survey shows that the average annual turnover (in- and outflow respectively) in the marginal group was roughly $40-45$ per cent during the period 1980-1991. Of the annual out- flow 5 percentage points had left for early retirement (Ministry of Finance 1995a).

41. The survey further reveals, that less than 15 per cent of the persons belonging to the marginal group in the three-year period 1980-82 were still in the marginal group in 1989-91 (Table 3). Another 22 per cent of the persons belonging to the marginal group in 1980-82 had left for early retirement in 1989-91. However, the survey does not reveal to what extent the inflow from the marginal group into early retirement that cannot merely be ascribed to age, is due to the employment difficulties for the persons belonging to the marginal group or rather reflects that the persons in the marginal group have other problems (e.g. disablement, see below) that influence their employment prospects.

Table 3. Flows out of long-term unemployment. Labour market status in subsequent years for 62000 persons belonging to the marginal group 1980-82 (age 15-66 years in 1980-82)

(per cent of reference group)

\begin{tabular}{|c|c|c|c|c|c|c|c|}
\hline & $\begin{array}{l}\text { Core } \\
\text { group }\end{array}$ & $\begin{array}{l}\text { Middle } \\
\text { group }\end{array}$ & $\begin{array}{l}\text { Risk } \\
\text { group }\end{array}$ & $\begin{array}{l}\text { Marginal } \\
\text { group }\end{array}$ & $\begin{array}{c}\text { Early } \\
\text { retirement }{ }^{1}\end{array}$ & Other $^{1}$ & Total \\
\hline $1980-1982$ & - & - & - & 100.0 & - & - & 100.0 \\
\hline 1983-1985 & 10.3 & 8.8 & 30.0 & 29.4 & 14.5 & 6.9 & 100.0 \\
\hline $1986-1988$ & 18.8 & 9.3 & 19.8 & 17.2 & 21.5 & 13.4 & 100.0 \\
\hline 1989-1991 & 20.2 & 6.5 & 17.0 & 13.8 & 22.7 & 19.5 & 100.0 \\
\hline
\end{tabular}

1. A significant share of inflow from the marginal group is due to age.

Note: The labour market groups are defined as follows: Core Group = persons who have been unemployed for less than 15 per cent of the time over a three year period. Middle group $=$ persons who have been unemployed for more than 15 and less than 40 per cent of the time. Risk group = persons who have been unemployed for more than 40 and less than 70 per cent of the time. Marginal group $=$ persons who have been unemployed for more than 70 per cent of the time. Early retirement $=$ persons in early retirement schemes. Other $=$ other persons no longer in the labour force and drop-outs due to death and age.

Source: Finansredegфrelse 1995 and Ministry of Finance 1995.

42. The survey also reveals that once in the marginal group it is difficult subsequently to regain a solid foothold in the labour market. Only 25-30 per cent of the persons belonging to the marginal group in 1980-82 were in the core group or the middle group, i.e. were unemployed less than 40 per cent of the time, in the three year period 1989-91 ${ }^{3}$. However, the outflow from the marginal group and into the groups with a stronger attachment to the labour market is downward biased, as the marginal group according to the definition in the survey - comprises a rather large group of people on social assistance due to problems which have no relation to labour market issues (i.e. drug-addicts, alcoholics, disabled, etc.).

3. For the definition of the labour market groups, see note in Table 3. 
43. Nevertheless, the empirical evidence suggest that there is substantial turnover among persons with weak labour market attachment, implying that the number of individuals who get "caught" in unemployment for a very long period of time is rather limited. Consequently, the social dimension of the problem is less severe than what the macroeconomic indicators of structural unemployment seem to suggest.

44. Summing up, the empirical evidence suggests that problems of structural unemployment in Denmark can primarily be ascribed to a poorly functioning market, whereas the employability problems of individuals seems to be less severe. Structural unemployment can by no means be equated with long-term unemployment. This conclusion is also supported by the fact that the incidence of long term unemployment varies considerably over the business cycle, while short term unemployment is more or less unaffected by cyclical variation in total unemployment (Figure 2). The fact that the number of persons who are affected by unemployment in the course of one year is, by and large, constant over the business cycle, implies that variation in total unemployment primarily affects the duration of the longer spells of unemployment ${ }^{4}$.

Figure 2. Cyclical variation in long term and short term unemployment

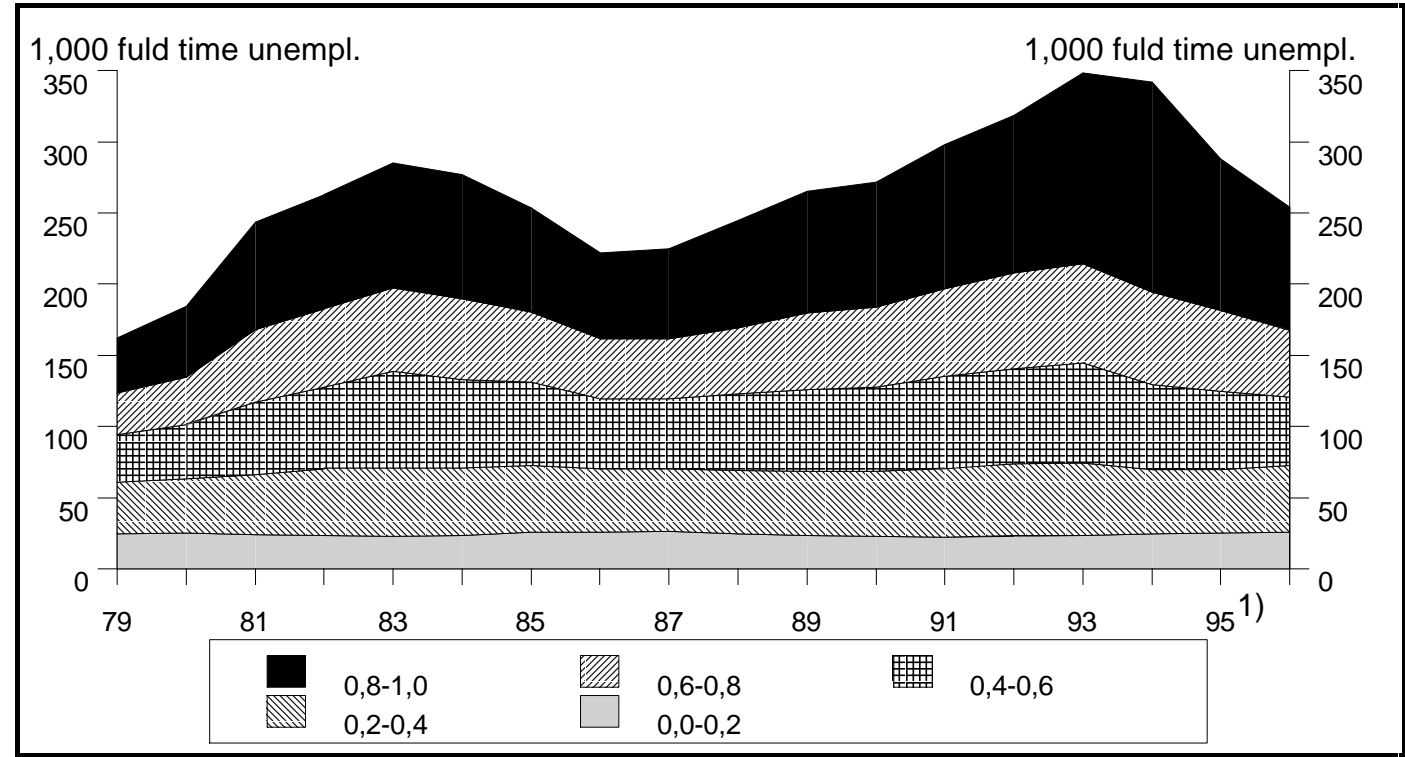

Note: The chart shows the number of unemployed (assessed on a full-time basis) who have been unemployed for a certain part of the year. $0-0.2=20$ per cent or less, $0.2-0.4=20-40$ per cent, etc.

Source: Danish Ministry of Finance and Statistics Denmark.

\subsection{Temporary lay-offs and other non-core benefits}

45. The marked difference in the cyclical variation in short term unemployment versus. long term unemployment can to some extent be ascribed to the importance of temporary lay-offs and measurement bias due to certain specific regulations in the Danish benefit system. Temporary lay-offs refer to an

4. Rapport om arbejdsmarkedets strukturproblemer (1992); Ministry of Finance. 
employee being fired with the tacit agreement that he or she can return to the job after a relatively short period of time. Although not actually employed, the involved persons have a strong attachment to their former employer and are not actively seeking other employment, and it is therefore an open question whether these persons should in fact be regarded as unemployed.

46. Due to a very liberal employment legislation and the Danish benefit system, with no waiting period for the unemployed and the employers obligation to pay benefits confined to two days, this type of temporary lay-offs are relatively common in Denmark. A rough estimate based on the number of unemployed returning to the same employer after a certain period of joblessness suggests that temporary lay-offs account for approximately $0.3-0.7$ per cent of the labour force (Ministry of Finance 1992).

47. The Danish benefit system implies other elements contributing to an upward bias in the measured unemployment. This is due to the fact that - in specific circumstances - one can receive benefits without being unemployed in the proper sense of the word:

i) Employees who are full time ensured but works part-time are entitled to supplementary unemployment benefit for a period of up to 12 months;

ii) Employees who are insured and who are not entitled to vacation paid by the employer are entitled to unemployment benefit while on vacation. During their vacation these persons are registered as unemployed although they are in fact employed;

iii) Persons registered as unemployed can in certain cases attend training programmes while receiving benefits;

iv) The measurement bias due to the existence of such non-core benefits can be estimated to roughly 2 per cent of the labour force.

48. The measurement bias due to non-core benefits is also reflected in the fact that the level of unemployment according to the national statistics - which registers the number of people actually receiving benefits - is 2-3 per cent higher than the level of unemployment according to the standardised surveys made by Eurostat. The major difference between the two is that the requirements elating to jobreadiness and job-seeking activities are more strict in the standardised surveys (Table 4).

Table 4. Official and standardised unemployment rates

\begin{tabular}{lrrr|rrrrrrr}
\hline & 1985 & 1990 & 1992 & 1994 & 1995 & 1996 & $1996 \mathrm{1} 1$ & $1996 \mathrm{2} 2$ & $1996 \mathrm{Q} 3$ & 1996Q4 \\
\cline { 2 - 10 } & & & & & & & & & & \\
Official rate & 9.1 & 9.7 & 11.3 & 12.2 & 10.3 & 8.8 & 9.2 & 8.9 & 8.8 & 8.2 \\
Standardised rate $^{1}$ & 7.1 & 7.7 & 9.2 & 8.2 & 7.1 & - & 6.4 & 6.1 & 6.1 & - \\
\hline
\end{tabular}

1. From 1994 the standardised rate is based on a sample collected in the second quarter, which is extended in accordance with the development in the official unemployment rate. Consequently, the figures for 1994-1996 are not directly comparable with the previous years.

Source: Statistics Denmark and Eurostat.

49. The difference between the official and the standardised unemployment rate has been reduced from 1994 to 1995. This may - at least in part - be due to the tightening of the availability requirements in the benefit system (see below). If this is the case, it also implies a reduction of the structural rate of unemployment. 
50. The total amount of temporary lay-offs and other non-core benefits can roughly be estimated to $2 \frac{1}{2}$ per cent. Taking the incidence of "purely" frictional unemployment into account, it thus seems very unlikely that structural unemployment can be reduced to a level below 4-5 per cent of the labour force corresponding to scarcely half the estimated structural level until 1994 - without changing the elements of the benefit system affecting temporary lay-offs and other non-core benefits. This implies that at an official rate of actual unemployment of 4-5 per cent, unemployment would be confined to politically "chosen" non-core benefits and relatively short spells of unemployment. In that case unemployment will still pose a financial problem, but the implications for output, employment and social cohesion will be limited.

51. Summing up, structural unemployment may be estimated to roughly 9 per cent of the labour force up until 1995, half of it reflecting serious economic and social problems and the other half reflecting frictional and what could be considered non-core benefits administered by the UIB-system. The rate is expected to drop to a level of 8 per cent by 1997 (see below).

\section{Policy implications}

52. As stated above, the level of structural unemployment reflects many different aspects of the economy. Consequently, structural unemployment can be influenced by a broad range of policy measures (Box 2).

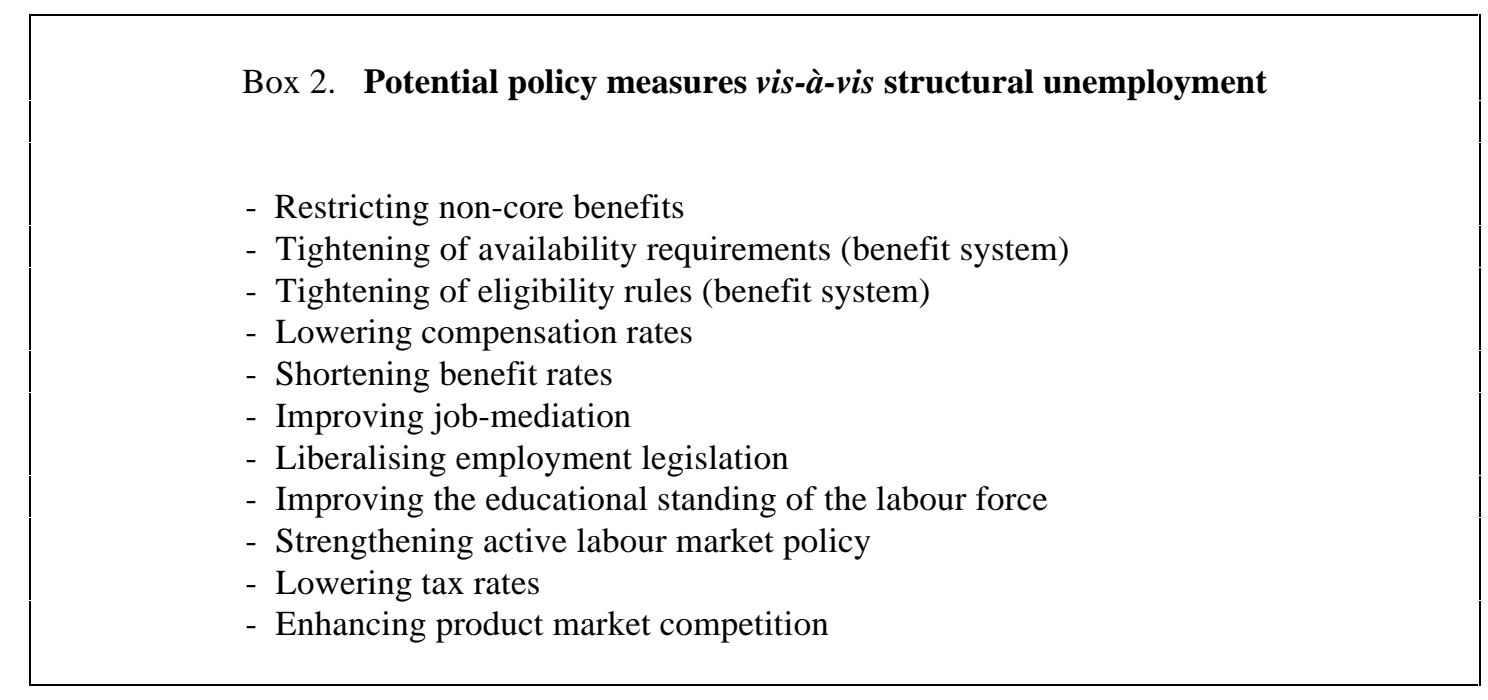

53. In consequence of the distributionary effects, avoiding across-the-board reductions in benefit rates and minimum-wages (which are negotiated by the social partners) is given high political priority in Denmark. Although it is approved that such measures - to some extent - will be effective in terms of lowering structural unemployment, analysis do suggest that important inroads could by achieved by other means, such as a range of skill-improving measures, administrative tightenings and targeted measures vis$\grave{a}$-vis long-term unemployed and more or less disabled persons.

54. The effectiveness of administrative tightenings compared to general benefit reductions is supported by a number of micro observations stemming from the experience with the reforms being implemented during the past three years. One such observation is the overwhelming popularity of the now abolished pre-early retirement scheme for 50-59 year-old being unemployed for more than one year. This 
scheme offered the opportunity of being "released" from the availability-for-work requirement in the benefit system while receiving a compensation of only 82 per cent of the unemployment benefit level. In a short time the scheme covered close to 100 per cent of the potential beneficiaries, corresponding to 1.7 per cent of the total labour force.

55. The majority of this group would alternatively have been able to continue in the benefit system for quite some time. Nevertheless, they proved willing to accept a lower compensation in return for not having to be available for the labour market. This suggests that administrative tightenings can indeed be effective too, and also that even fairly large changes in compensation rates are not necessarily as effective.

56. The analysis in general suggest, that employability problems of individuals are not the dominant matter of concern in Denmark. Therefore general cost-reduction for employers caused by income-related subsidies or tax-expenditures (such as an Earned Income Tax Credit or targeted reductions of indirect labour costs, which in any case are very low in Denmark) are not likely to improve much. Due to relatively high marginal tax rates, high benefit levels and a compressed wage structure such measures would lead to severe loss of revenue and/or increases in effective marginal taxes rates affecting negatively the general functioning of the labour market ${ }^{5}$.

\subsection{Measures undertaken since 1993}

57. Since 1993, the Danish labour market system has undergone considerable changes, most importantly related to the system of active labour market policy and the interaction with the UIB-system. Among the most important changes are:

- The benefit period has been reduced from - in some cases - up to nine years to a maximum of five years ${ }^{6}$;

- The possibility of obtaining right to benefits for another two-and-a-half years by participating in job-training activities for six months has been abolished. It now requires 52 weeks of unsubsidised works within the last three years to recommence a benefit period;

- Full time activation through job-offers, training and education is now obligatory after two years of unemployment ${ }^{7}$. The availability requirements during the first two years of unemployment have also been strengthened. The administrative practice is monitored more closely, a special body with the single task of ensuring the enforcement of availability requirements has been established and a new and better statistical coverage of the administrative practice has been prepared;

- The responsibility for implementing the ALMP-strategy has been decentralised in order to make the effort more flexible and directly oriented toward the specific needs in different regions;

5. OECD (1995), Employment Outlook and Ministry of Finance (1995), Unemployment traps and poverty traps - what matters for the trade-off? According to these studies, Denmark does not meet the criteria for an EITC-system to beneficial.

6. The reduction of the benefit period will be fully implemented in the course of 1998

7. Full time activation after two years of unemployment is gradually phased in until 1998. 
- Within two years of unemployment an individual action plan is formulated, setting out the specific initiatives to be taken in the "active period";

- Within the first two years of unemployment, the public employment service can use advanced targeted activation directed at groups having a particularly high risk of long-term unemployment. Advanced activation can also be used to prevent bottlenecks from emerging in local labour markets;

- The further education system has been strengthened inter-alia through paid leave schemes and free admittance and a new training strategy for young unemployed without a qualifying education has been implemented. After six months of unemployment young people between 18 and 25 years without a qualifying education are required to take up education for at least 18 months while the compensation level is reduced to a maximum of 50 per cent of the normal benefit level. Benefits are conditional on participation in measures.

58. The shortening of the benefit period from - in some cases - nine years to a maximum of five years and the tightening of the availability requirements have strongly enhanced the incentives of the unemployed to find an ordinary job. Furthermore, the eligibility rules have been changed so that access to unemployment benefits can no longer be obtained by way of participation in active labour market measures, but only by way of unsubsidised jobs. Cutting this link has been decisive in order to improve the flexibility and renew the focus of active labour market policy towards qualifying for ordinary jobs (and not prolonging the benefit period).

59. In the longer run, the most important change may prove to be the introduction of compulsive full time activation after two years of unemployment, which on the one hand serves to maintain and improve the skills of the long term unemployed, and on the other hand acts as an effective test of availability. No matter what kind of activation is offered, the compensation of the unemployed do not exceed the level of unemployment benefits during the period of full time activation. Hence, the unemployed have strong incentives to seek ordinary employment. Moreover, the effect of the mandatory full time activation is strengthened in consequence of the tightening of the employment criteria in the benefit system, which implies that 52 weeks against previous 26 weeks of unsubsidised work within three years is now required to recommence a benefit period. Hence, it has become much more difficult to "avoid" full-time activation by way of shorter spells of employment.

60. There is little doubt that full time activation schemes with a compensation equal to regular benefits are effective means of testing availability and strengthening incentives for active job-search. However it will be costly - and counterproductive - to introduce full-time activation schemes or the like for unemployed with only shorter spells of unemployment behind them, the reason being that such schemes "disturb" the regular search-process which for the major part of the newly unemployed results in an ordinary job within a relatively short time.

61. The reorganisation of the active labour market policy has improved the possibilities of diverting the efforts made, making it possible to take in hand at an early stage groups with high risk of long-term unemployment and to establish longer programmes for the group of unemployed who have already lost foothold in the labour market. The reorganisation of the active labour market policy has notably been directed towards the prevention of long- term unemployment. However, it also implies a strengthening of the qualifications of the unemployed in general, which together with an improvement in the efficiency of local employment agencies serves to reduce mismatch problems. 
62. Qualifications of the unemployed are improved by way of the introduction of individual action plans, the new paid leave schemes (Box 3), and the fact that offers of job-training no longer serve as a means of prolonging the benefit period. These changes have entailed a marked shift in the composition of the activation towards training and education activities. Moreover, the new steering principles with regional boards being responsible for the priorities given to different activities seem to have improved the effectiveness of general job-matching and prevention of bottlenecks in local labour markets. In 1983-86, a reduction of unemployment resulted in a substantial increase in the number of unfilled vacancies. During the period 1993-95, unemployment has been reduced even more but the number of unfilled vacancies has remained stable.

63. It has been argued, that the bulk of Danish unemployment problems are not due to employability problems of individuals. However, such problems obviously also exist to some extent. The analysis implies, that measures vis-à-vis hard-core unemployment must be carefully targeted. The activation measures for long-term unemployed constitute one such targeted measure. Another is intensified efforts to set up protected jobs and promoting the social responsibility of firms. A third is a subsidy for private home services, an activity which in 1995 employed approximately 2500 persons on a full-time basis, mainly low-skilled and thus directed towards lowering structural unemployment. The home services attract activity in the only sectors which: i) compete with black labour and do-it-yourself activities; ii) employ low skilled workers and iii) avoids dead-weight loss as no activity was apparent before. The experiment has shown that the potential side effects of a subsidy is limited.

64. Summing up, the different policy measures implemented during the last two to three years are expected to enhance the qualifications of the labour force over the medium term, prevent long-term unemployment, reduce the risk of bottlenecks emerging and strengthen the incentives of the unemployed to find a job thereby reducing structural unemployment. 


\section{Box 3. The Danish paid leave schemes}

The new paid leave schemes were introduced in 1994 and did up by some 2.5 per cent of the labour force in 1996. There are three such schemes:

- $\quad$ One is the leave for further education (1.5 per cent of the labour force). It should be noted that this scheme to a large extent substitutes old ALMP-measures for unemployed. For employees on educational leave, recent surveys shows a high degree of contentment for participants as well as for their employers;

- $\quad$ The second is the child-care leave scheme (1.0 per cent of the labour force). This undoubtedly reduces the labour force, but probably includes "dead-weight" loss due to beneficiaries who would not have been working anyway. The dead-weight loss has financial implications, but does not affect the labour market negatively. Prior to the introduction of the paid leave schemes, the maternity leave period in Denmark was relatively short compared to other countries;

- $\quad$ The third is the sabbatical leave scheme to which access is difficult and which is taken up by less than 1000 persons.

The leave schemes are perceived not to have caused measurable bottleneck problems in the private sector. About 60 per cent of the formerly-employed persons on leave were employed in the public sector, where this outflow from the labour force has given rise to certain problems especially in the health sector and the social sector.

Even if the aggregate leave figures exaggerate the scale of the problem due to dead-weight loss and substitution from the transfers, the leave schemes will no doubt reduce the labour force and hence employment in the longer run.

The leave schemes - together with the pre-early retirement scheme for 50-59-year-old long-term unemployed - did reduce the labour force and thus unemployment in the short run with an estimated 50-60 000 persons from 1993 to 1996. The leave schemes were tightened and the pre-early retirement scheme was abolished from the 1996 onwards. The number of participants are now falling significantly.

65. The expected drop in structural unemployment is also reflected in the NAIRU- and ITRUindicators (Figure 1). Actual unemployment has thus come down from more than 12 per cent of the labour force to about 8 per cent (end-1996 figures) without raising inflation. This large drop reflects both an initially large cyclical component, but also lower structural unemployment - the latter undoubtedly being related to the labour market measures undertaken ${ }^{8}$.

8. Between one third and one half of the drop in unemployment reflects a fall in the labour force due to the leave schemes, etc. If not combined with the efforts made to reduce structural unemployment, the leave schemes might have led to higher inflation. It has been questioned if the measured drop in structural unemployment is merely a technical effect from disabled labour market participants being transferred from unemployment benefits to the leave schemes and pre-early retirement. Such an effect is however estimated to be small, as the number of long-term unemployed entering these schemes has been almost 


\section{Concluding remarks}

66. With the policy measures now implemented, it seems likely that structural problems of unemployment in the Danish labour market has been taken reasonably well in hand. The measures now implemented are expected to induce a drop in structural unemployment to a level of approximately 8 per cent by 1997 and 7 per cent by the year 2000, as measures are phased in completely and as the skillimproving efforts begin to work. Such a reduction of structural unemployment might cause a shift of political focus towards other working-age benefits.

67. Over the last 30 years the employment rate for the working-age population (age 15-66) has been relatively constant at a level around 70 per cent. Meanwhile, the share of non-employed receiving public benefits has been steadily increasing. Hence, in 1994 almost 90 per cent of the non-employed persons in the working age (27 per cent of working-age population) received some kind of benefits, of which approximately one third were unemployed.

68. In spite of a high unemployment, the Danish employment rate is relatively high compared to other countries, and contrary to the experience in other EU-countries it has displayed no tendency to fall. Despite the difficulties of gathering comparable data, the available data seem to suggest that the large number of non-employed receiving some kind of benefits are shared by other EU-countries, whereas the number of other non-employed (including housewives) are more limited in Denmark (OECD 1996b).

69. Except for the unemployment benefit, the major part of the existing benefits for people in the working age are to be considered as welfare goods, and to a large extent they replace previous support from families, etc. Consequently, the labour market implications of the relatively large number of people receiving these benefits should not be overestimated. To a large extent, the numbers reflect solving out social problems - which are not labour market induced - supporting education and the role of the public sector in redistributing income over the life-cycle (probably affecting savings decisions more than labour market decisions).

70. While many of the working-age transfers do not constitute other problems, they do impose serious strain on public finances. Even though structural unemployment may be reduced to the perceived minimum of 5 per cent (see above), the remaining 20-25 per cent of the working-age population receiving benefits will still be matter of serious concern - at least in relation to public finances and in relation to the forthcoming ageing population problems.

71. Most of working age transfers might be considered a theme for making policy-priorities between transfers, the provision of public sector services and taxation. There is also an important labour market spill-over. But it seems out of line with international experience, out of line with the characteristics of working-age transfers and out of line with most single individuals working-life characteristics to expect employment rates above 75-80 per cent of the working age population.

balanced by a comparable drop in the number of long-term unemployed entering various activation measures. The schemes has thus mainly worked as a general reduction in the labour force. 


\section{BIBLIOGRAPHY}

LAYARD, R., S. NICKELL and R. JACKMAN (1991). "Unemployment - Macroeconomic Performance and the Labour Market". Oxford University Press.

LAXTON, Douglas, Guy MEREDITH AND David ROSE (1995). "Asymmetric Effects of Economic Activity on Inflation”. IMF Staff Papers Vol. 42.2.

MINISTRY OF FINANCE (1992). Rapport om arbejdsmarkedets strukturproblemer.

MINISTRY OF FINANCE (1995a). A note on product market competition in Denmark and Finansredegфrelse.

MINISTRY OF FINANCE (1995b). Unemployment traps and poverty traps - what matters for the tradeoff ?

MINISTRY OF FINANCE (1996): Statistisk tiårsoversigt (various volumes), Statistics Denmark, and Finansredegфrelse.

OECD (1995). OECD Economic Studies, No. 4.

OECD (1996a): The OECD Employment Outlook. Paris.

OECD (1996b): The OECD Economic Survey of Netherlands. Paris.

THE EUROPEAN COMMISSION (1995). Employment in Europe.

TURNER, Dave (1995): "Speed limit and Asymmetric Inflation Effects from the Output Gap in the Major Seven Economies". OECD Economic Studies No. 24, 1995/II. 


\section{ECONOMICS DEPARTMENT \\ WORKING PAPERS}

A complete list of Working Papers is available on request.

182. The United Kingdom NAIRU: Concepts Measurements and Policy Implications (September 1997) Chris Melliss and A. E. Webb

181. Globalisation and Linkages: Macro-Structural Challenges and Opportunities (September 1997) Pete Richardson (editor)

180. Regulation and Performance in the Distribution Sector (September 1997) Dirk Pilat

179. Measurement of Non-Tariff Barriers

(July 1997) Alan V. Deardorff and Robert M. Stern

178. The NAIRU-Concept: A Few Remarks

(July 1997) Karl Pichelmann and Andreas Ulrich Schuh

177. Structural Unemployment in Finland

(July 1997) Pasi Holm and Elina Somervouri

176. Taxation and Economic Performance

(June 1997) Willi Leibfritz, John Thornton and Alexandra Bibbee

175. Long-Term Interest Rates in Globalised Markets

(May 1997) Hans Christiansen and Charles Pigott

174. International Implications of European Economic and Monetary Union

(May 1997) Norbert Funke and Mike Kennedy

173. The NAIRU in Japan : Measurement and its Implications

(February 1997) Fumihira Nishizaki

172. The Unemployment Problem - A Norwegian Perspective

(February 1997) Steinar Holden

171. The Reliability of Quarterly National Accounts in Seven Major Countries : A User's Perspective (February 1997) Robert York and Paul Atkinson

170. Confidence Indicators and their relationship to changes in Economic Activity (October 1996) Teresa Santero and Niels Westerlund

169. Labour Productivity Levels in OECD Countries : Estimates for Manufacturing and Selected Service Sectors

(September 1996) Dirk Pilat 
168. Ageing Populations, Pension Systems and Government Budgets : Simulations for 20 OECD Countries

(September 1996) Deborah Roseveare, Willi Leibfritz, Douglas Fore and Eckhard Wurzel

167. Modelling the Supply Side of the Seven Major OECD Economies

(August 1996) Dave Turner, Pete Richardson and Sylvie Rauffet

166. Size Distribution of Output and Employment: a Data Set for Manufacturing Industries in Five OECD Countries, 1960 s-1990

(August 1996) Bart van Ark and Erik Monnikhof

165. Trade and Competition: Frictions after the Uruguay Round

(July 1996) International Trade and Investment Division

164. Corporate Governance, Competition and Performance

(June 1996) Colin Mayer

163. Fiscal Relations within the European Union

(April 1996) Peter Hoeller, Marie-Odile Louppe and Patrice Vergriete

162. Mark-up Ratios in Manufacturing Industries

(April 1996) Joaquim Oliveira Martins, Stefano Scarpetta and Dirk Pilat

161. Innovation, Firm Size and Market Structure: Schumpetarian Hypotheses and Some New Themes (April 1996) George Symeonidis

160. Valuing the Right to Tax Incomes: An Options Pricing Approach

(April 1996) Teun Draaisma and Kathryn Gordon

159. Innovation and Competitive Advantage

(October 1995) P. A. Geroski

158. Monetary Policy at Price Stability: A Review of Some Issues

(September 1995) Malcolm Edey, Norbert Funke, Mike Kennedy and Angel Palerm

157. Technical Progress, Factor Productivity and Macroeconomic Performance in the Medium Term (September 1995) Claude Giorno, Pete Richardson and Wim Suyker

156. Ageing Populations, Pension Systems and Government Budgets: How do they Affect Savings (August 1995) Willi Leibfritz, Deborah Roseveare, Douglas Fore and Eckhard Wurzel

155. The Determinants of Real Long-Term Interest Rates: 17 Country Pooled Time-Series Evidence (June 1995) Adrian Orr, Malcolm Edey and Michael Kennedy

154. An Assessment of Financial Reform in OECD Countries

(May 1995) Malcolm Edey and Ketil Hviding

153. Markets for Tradeable $\mathrm{CO}_{2}$ Emission Quotas, Principles and Practice (February 1995) Graciela Chichilnisky and Geoffrey Heal 
GENERAL DISTRIBUTION

\section{ECONOMICS DEPARTMENT}

\section{WORKING PAPERS}

This series of Working Papers is designed to make available, to a wider readership, selected studies which the Department has prepared for use within OECD. Authorship is generally collective, but main individual authors are named. The Papers are generally available in their original language, English or French, with a summary in the other.

The views expressed in this paper are those of the author(s) and do not necessarily reflect those of the OECD or of the governments of its Member countries.

Comment on the Papers is invited, and may be sent to OECD, Economics Department, 2 rue André Pascal, 75775 Paris Cedex 16, France. Additional copies of the Papers, on a limited basis, can be forwarded on request. 